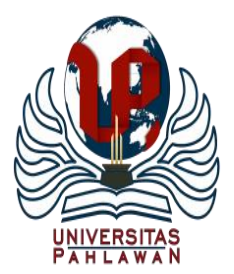

Edukatif : Jurnal Ilmu Pendidikan Volume 3 Nomor 3 Tahun 2021 Halm 728-737

EDUKATIF: JURNAL ILMU PENDIDIKAN

Research \& Learning in Education

https:/ledukatif.org/index.php/edukatif/index

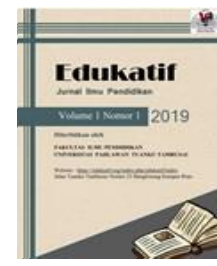

\title{
Analisis Kepemimpinan Kepala Sekolah, Penerapan Disiplin dan Pengawasan Terhadap Etos Kerja
}

\author{
Suyitno \\ Sekolah Tinggi Ilmu Ekonomi Indonesia Malang \\ E-mail : drsuyitno@yahoo.co.id
}

\begin{abstract}
Abstrak
Etos kerja merupakan sifat mendasar dan cara individu memberikan ekspresi terhadap kerja yang dapat menjadi pendorong atau penggerak untuk meraih keberhasilan. Seorang guru yang mempunyai etos kerja yang tinggi cenderung mempunyai sikap positif terhadap pekerjaannya. Penelitian ini mengkaji tentang kepemimpinan kepala sekolah, penerapan disiplin, dan pengawasan terhadap etos kerja guru di SMA Negeri Kabupaten Tulungagung. Data dikumpulkan dari 244 responden dengan menggunakan kuesioner, wawancara dan dokumen serta menggunakan SPSS 17.0 untuk analisis regresi berganda, uji F dan uji t. Hasil penelitian menunjukkan terdapat pengaruh yang signifikan antara (1) kepemimpinan kepala sekolah (X1) terhadap etos kerja guru $(\mathrm{Y}) \mathrm{r}=0,532 ; \mathrm{p}=.000 ;$ (2) penerapan disiplin $(\mathrm{X} 2)$ terhadap etos kerja guru $(\mathrm{Y}) \mathrm{r}=0,301 ; \mathrm{p}=$ 0,013; (3) supervisi (X3) terhadap etos kerja guru (Y) $r=0,344$; $p=0,005$; dan (4) kepemimpinan kepala sekolah (X 1), penerapan disiplin (X2), dan supervisi (X3) terhadap etos kerja guru secara simultan pada Rsquare $=0,605 ; \mathrm{p}=.000$. Kepemimpinan kepala sekolah, pelaksanaan disiplin dan supervisi sangat berpengaruh signifikan terhadap etos kerja guru. Diantara ketiga variabel bebas tersebut, variabel kepemimpinan kepala sekolah memiliki pengaruh dominan terhadap etos kerja guru.

Kata kunci: kepemimpinan kepala sekolah, disiplin, pengawasan, etos kerja guru.
\end{abstract}

\begin{abstract}
Work ethic is a fundamental trait and individual way of giving expression to work that can be a driving force or driving force for success. A teacher who has a high work ethic tends to have a positive attitude towards his job. This study investigates the principal's leadership, implementation of discipline, and supervision on work ethic of teacher's in the Public Senior High School at Tulungagung Regency. Data were collected from 244 respondents using questionnaire, interview and document and used SPSS 17.0 for analysis on multiple regression, F-test and t-test. The findings showed the significant effects existed between (1) the principal leadership (X1) on work ethic of teacher $(Y) r=0.532 ; p=.000 ;(2)$ implementation of discipline (X2) on the work ethic of teacher $(Y) r=0.301 ; p=.013$; (3) the supervision $(X 3)$ on the work ethic of teacher $(Y) r=$ $0.344 ; p=.005$; and (4) the principal leadership (X 1), implementation of discipline (X2), and the supervision (X3) to the work ethic of teacher simultaneously at Rsquare $=0.605 ; p=.000$. Principal's leadership, discipline implementation and supervision have a significant effect on teacher work ethic. Among the three independent variables, the principal's leadership variable has a dominant influence on the work ethic of the teacher.
\end{abstract}

Keyword : principal's leadership, discipline, supervision, teacher's work ethic.

Copyright (c) 2021 Suyitno

$\triangle$ Corresponding author

Email : drsuyitno@yahoo.co.id

DOI : https://doi.org/10.31004/edukatif.v3i3.438

ISSN 2656-8063 (Media Cetak)

ISSN 2656-8071 (Media Online)

Edukatif : Jurnal Ilmu Pendidikan Vol 3 No 3 Tahun 2021 p-ISSN 2656-8063 e-ISSN 2656-8071 


\section{PENDAHULUAN}

Perubahan lingkungan organisasi yang dinamis menyebabkan tantangan yang dihadapi lembaga atau organisasi sangat komplek, termasuk organisasi bidang pendidikan. Para pemimpin lembaga pendidikan dari semua jenis organisasi pendidikan juga menghadapi banyak tantangan yang sulit, terutama berkenaan dengan tuntutan masyarakat sebagai basis yang harus mereka layani. Masyarakat tidak lagi diam dan menerima begitu saja produk-produk yang dihasilkan organisasi pendidikan. Mereka menuntut organisasi pendidikan mampu menghasilkan produk yang lebih baik yang lebih dapat dirasakan manfaatnya. Kemampuan satuan pendidikan dalam melayani masyarakat serta warganya mampu menjadi salah satu indikator kualitas sumber daya manusia di dalamnya (Puspitasari, 2019).

Untuk meningkatkan mutu pendidikan, peranan pemimpin menjadi sangat penting, sebab esensi dari pemimpin adalah usaha untuk mempengaruhi orang lain agar menyumbangkan keahliannya, baik untuk bertindak sesuai kapasitas yang dimiliki maupun untuk tumbuh dan berkembang secara terus menerus. Hal tersebut sejalan juga dengan hasil penelitian yang dilakukan oleh Ja'far (2019) yang menyatakan bahwa konsep kepemimpinan inovatif mengarah kepada kepemimpinan yang efektif yakni kepemimpinan yang menjadi panutan, perintis, penyelaras, dan pembudaya sehingga melahirkan pemimpin yang memiliki prinsip kuat dan berkarakter. Pengaruh diperuntukan untuk menjual gagasan, untuk memperoleh penerimaan dari kebijakan yang dibuat atau program kerja yang direncanakan untuk memotivasi karyawan supaya mendukung dan melaksanakan keputusan yang dibuat. Dengan kata lain, pemimpin tidak hanya dapat mengatakan kepada bawahan apa yang harus dikerjakan, tetapi juga dapat mempengaruhi bagaimana bawahan melaksanakan perintah pimpinan.

Keberhasilan pendidikan di sekolah sangat ditentukan oleh keberhasilan kepala sekolah dalam mengelola tenaga kependidikan yang tersedia di sekolah (Ballu, Manu and Meha, 2021). Kepala sekolah merupakan salah satu komponen pendidikan yang berpengaruh dalam meningkatkan kinerja guru. Kepala sekolah bertanggung jawab atas penyelenggaraan kegiatan pendidikan, administrasi sekolah, pembinaan tenaga kependidikan lainnya, dan pendayagunaan serta pemeliharaan sarana dan prasarana. Hal tersebut menjadi lebih penting sejalan dengansemakin kompleksnya tuntutan tugas kepala sekolah, yang menghendaki dukungan kinerja yang semakin efektif dan efisien.

Guru dituntut memiliki etos kerja yang tinggi, yakni karakteristik yang khas yang ditunjukan seorang guru menyangkut semangat, dan kinerjanya dalam bekerja (mengajar), serta sikap dan pandangannya terhadap terhadap kerja. Etos kerja guru dalam pengertian lain yaitu guru yang orang yang memiliki etos kerja yang baik biasanya dapat lebih bertanggungjawab untuk menyelesaikan kuantitas tugasnya dengan lebih efektif. Semakin tinggi etos kerja seseorang, intensitas penyelesaian tugas-tugas dalam pekerjaan relatif semakin tinggi (Fitri dan Hakim, 2020). Kualitas penyelenggaraan pendidikan di sekolah sangat tergantung dari seberapa tinggi etos kerja guru-gurunya. Melalui etos kerja yang tinggi akan memungkinkan seorang guru akan memiliki motivasi serta mampu dan mengembangkan dirinya, berinovasi serta melaksanakan tugas pokok dan fungsi sebagai pendidik yang profesional. Sementara itu Sinamo seperti dikutip oleh Wahyuningsih (2016) mendeskripsikan ciri-ciri orang yang memiliki etos kerja memiliki pandangan hidup bahwa: (a) Kerja adalah rahmat; (b) Kerja adalah amanah; (c) Kerja adalah panggilan; (d) Kerja adalah ibadah; (c) Kerja adalah seni; (t) Kerja adalah kehormatan; (g) selalu berpartisipasi; dan (h) Kerja adalah pelayanan.

Pandipa (2018) mengemukakan tentang pentingnya kedisplinan. Kedisiplinan merupakan fungsi operatif Manajemen Sumber Daya Manusia yang terpenting karena semakin baik disiplin karyawan, semakin tinggi prestasi kerja yang dapat dicapainya. Tanpa disiplin yang baik, sulit bagi organisasi mencapai hasil yang optimal. Kedisiplinan adalah kesadaran dan kesediaan seseorang mentaati semua peraturan perusahaan dan norma-norma sosial yang berlaku. Kesadaran adalah sikap seseorang yang secara sukarela mentaati semua peraturan dan sadar akan tugas dan tanggung jawabnya. Kesediaan adalah suatu sikap, tingkah laku dan 
perbuatan seseorang yang sesuai dengan peraturan perusahaan baik yang tertulis maupun tidak. Kedisiplinan dapat diartikan bilamana karyawan datang dan pulang tepat waktunya mengerjakan semua pekerjaannya dengan baik, mematuhi semua peraturan perusahaan dan nonna-nonna sosial yang berlaku. Kedisiplinan harus ditegakkan dalam suatu organisasi perusahaan, karena tanpa dukungan disiplin karyawan yang baik, maka sulit perusahaan untuk mewujudkan tujuannya. Jadi, kedisiplinan adalah kunci kdberhasilan suatu perusahaan mencapai tujuan. Menurut Suryadi dalam Siagian (2016) bahwa disiplin kerja dapat juga diartikan sebagai sikap menghargai, patuh, taat terhadap peraturan dan tata tertib yang berlaku di tempat kerja yang dilakukan secara sukarela dengan penuh tanggung jawab dan siap menerima sanksi jika melanggar tugas dan wewenang.

Pengawasan merupakan kegiatan untuk mengamati, menilai, mengarahkan pekerjaan, wewenang yang diserahkan oleh atasan terhadap bawahannya sehingga jika tidak ssuai dengan sttandar yang ditentukan akan dapat menimbulkan diberikan sanksi terhadap bawahan secara struktural, yang dilakukan secara kontiniu dan berkesinambungan. Pengawasan adalah segenap kegiatan untuk meyakinkan dan menjamin bahwa pekerjaanpekerjaan dilakukan sesuai dengan rencana yang ditetapkan, kebijakan-kebijakan yang telah digariskan dan perintah-perintah yang telah diberikan dalam rangka pelaksanaan rencana tersebut (Gun Gun Gunanjar, 2019). Pengawasan harus mengukur apa yang telah dicapai, menilai pelaksanaan, serta mengadakan tindakan perbaikan dan penyesuaian yang dianggap perlu. Kinerja pegawai dan pengawasan sebagai determinan yang penting dalam pencapaian tujuan organisasi. Pengawasan sangat mempengaruhi dalam efektifitas kinerja pegawai. Jika pengawasan lemah, maka pekerjaan menjadi tidak selesai atau terbengkelai. Bila ini terjadi terus menerus dan cukup lama akan mengakibatkan keborosan-keborosan dan pada akhirnya akan mengakibatkan kerugian kantor atau instansi yang bersangkutan. Mutakallim (2016) menyatakan bahwa pengawasan bisa didefinisikan sebagai suatu usaha sistematis oleh manajemen bisnis untuk membandingkan kinerja standar, rencana, atau tujuan yang telah ditentukan terlebih dahulu untuk menentukan apakah kinerja sejalan dengan standar tersebut dan untuk mengambil tindakan penyembuhan yang diperlukan dan melihat bahwa sumber daya manusia digunakan dengan seefektif dan seefisien mungkin di dalam mencapai tujuan. Adapun indikator pengawasan adalah: 1) Tingkat membandingkan pengukuran standar hasil kerja. 2) Pengukuran hasil kerja, 3) Tingkat koreksi.

Dalam banyak praktek pengelolaan lembaga pendidikan, etos kerja seseorang seorang guru sebagai anggota organisasi banyak dipengaruhi oleh faktor lain. Seorang guru yang mempunyai etos kerja yang tinggi cenderung mempunyai sikap positif terhadap pekerjaannya. Sikap tersebut nampak pada kedisiplinan dalam bekerja, bertanggung jawab, kreatif, inovatif, inisiatif, produktif, bekerja keras dan bersungguh-sugguh, bersemangat dan sebagainya. Seorang pekerja yang mempunyai sikap positif terhadap pekerjaannya akan memperlihatkan produktivitas yang tinggi dan sebaliknya jika pekerja bersikap negatif terhadap pekerjaannya maka tingkat produktivitasnya rendah. Kajian secara teoritis dan bukti empirik telah menjelaskan hal tersebut antara lain adalah hasil studi dari Herana Budi, (2020) menunjukkan ada pengaruh yang positif dari persepsi guru tentang gaya kepemimpinan kepala sekolah terhadap etos kerja guru di SMP Negeri 6 Boyolali. Sementara studi Hanif Nur Hidayah (2019) menjelaskan hasil uji hipotesis diperoleh motivasi dan disiplin kerja berpengaruh terhadap etos kerja guru di SMK PGRI Ciwastra Kota Bandung. Penelitian yang dilakukan Ketut Sukarma, Nyoman Dantes (2014) juga telah menunjukkan bahwa supervisi klinis secara signifikan dapat meningkatkan etos kerja dan kemampuan guru mengelola proses pembelajaran pada para guru SD seKecamatan Buleleng. Penelitian yang dilakukan Chadijah (2019) menunjukkan bahwa supervisi akademik pengawas sekolah dapat meningkatkan penyusunan rencana pelaksanaan pembelajaran terhadap etos kerja mandiri guru SD Kota Lhokseumawe. Beberapa kajian secara empiris tersebut masih menunjukan kajian secara terpisah antara variabel kepemimpinan kepala sekolah, penerapan disiplin dan pengawasan terhadap etos kerja guru. Pada penelitian ini mengkaji dari ketiga variabel bebas tersebut yakni kepemimpinan kepala sekolah, penerapan disiplin dan pengawasan secara bersama-sama untuk menerangkan etos kerja guru sebagai variabel terikat dalam satu lokasi penelitian yakni di SMA Negeri se Kabupaten Tulungagung. Berdasarkan 
731 Analisis Kepemimpinan Kepala Sekolah, Penerapan Disiplin, Dan PengawasanTerhadap Etos KerjaSuyitno

DOI: https://doi.org/10.31004/edukatif.v3i3.438

uraian tersebut, maka kajian ini bertujuan untuk membuktikannya sesuai dengan rumusan masalah yang diajukan, yakni pengaruh kepemimpinan kepala sekolah, penerapan disiplin, dan pengawasan berpengaruh terhadap etos kerja guru di SMA Negeri se Kabupaten Tulungagung.

\section{METODE PENELITIAN}

Penelitian ini dilakukan dengan pendekatan kuantitatif dengan jenis eksplanatori untuk menguji pengaruh Etos Kerja Guru sebagai variabel terikat (Y) dan variabel bebas (X) terdiri dari Kepemimpinan kepala sekolah (X1), Penerapan disiplin (X2), dan Pengawasan (X3) di SMA Negeri se Kabupaten Tulungagung. Data penelitian diperoleh dengan kuesioner yang telah diuji validitas dan reliabilitasnya kepada 244 responden dengan metode random sampling dari SMA Negeri se Kabupaten Tulungagung.

Teknik analisis data yang digunakan pada penelitian ini adalah regresi linier berganda dengan menggunakan alat bantu statistik SPSS versi 17, formulasi model dari analisis regresi linier berganda dalam penelitian ini adalah sebagai berikut :

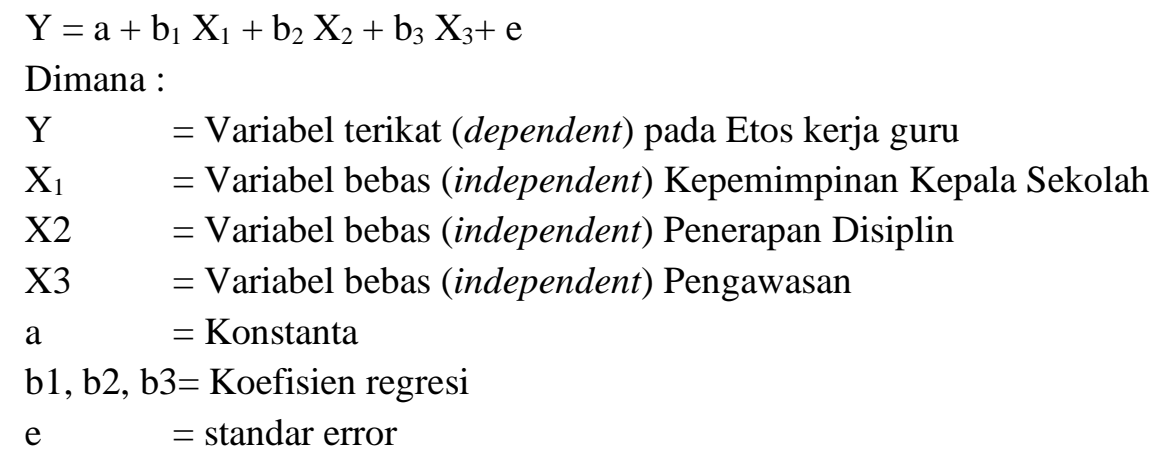

Selanjutnya untuk menguji hipotesis yang diajukan, dilakukan uji hipotesis secara parsial (uji-t), uji simultan (uji F) dengan kriteria yang digunakan dalam analisa regresi linier berganda ini adalah:

Ho $: \mathrm{b} 1-\mathrm{b}=0$ : Tidak adanya pengaruh yang berarti diantara variabel bebas terhadap variabel terikat.

Hi : b1 - $b \neq 0$ : Ada pengaruh yang berarti antara variabel bebas terhadap variabel terikat.

Untuk menilai independensi setiap variabel bebas maka perlu memenuhi asumsi-asumsi klasik agar diperoleh hasil yang tidak bias dan eflsien dari model analisis Regresi Linier Berganda dengan metode kuadrat terkecil atau OLS (Ordinary Least Square) terhadap variabel yang diamati. Adapun uji asumsi klasik yang digunakan adalah gejala Multikolinieritas, heteroskedastisitas, Autokorelasi, dan Normalitas.

\section{HASIL DAN PEMBAHASAN}

Hasil statistik melalui uji regresi berganda pada penelitian ini didapat hasil seperti tabel di bawah ini :

Tabel 1

Ringkasan Hasil Regresi Linier Berganda

\begin{tabular}{|l|r|r|r|}
\hline \multicolumn{1}{|c|}{ Variabel } & Koef. Regresi & \multicolumn{1}{c|}{ Std. error } & \multicolumn{1}{c|}{ t. Stat } \\
\hline $\begin{array}{l}\text { Kepemimpinan } \\
\text { Kepala Sekolah }\end{array}$ & 0,5331 & 0,088235 & 3,868 \\
\hline Penerapan Disiplin & 0,3018 & 0,388310 & 3,283 \\
\hline Pengawasan & 0,3445 & 0,323351 & 3,332 \\
\hline Konstanta & 1,3044 & 0,284369 & 2,756 \\
\hline
\end{tabular}


732 Analisis Kepemimpinan Kepala Sekolah, Penerapan Disiplin, Dan PengawasanTerhadap Etos KerjaSuyitno

DOI: https://doi.org/10.31004/edukatif.v3i3.438

Variabel terikat: Etos kerja guru

\begin{tabular}{|l|l|}
\hline Multiple R & 0,67319 \\
\hline R square & 0,60518 \\
\hline Adjusted R. Square & 0,62402 \\
\hline Standart Error & 60,67638 \\
\hline F. Ratio & 15,53938 \\
\hline Durbin Watson Test & 1,85715 \\
\hline \multicolumn{2}{|l|}{ Sumber : print out }
\end{tabular}

Sumber : print out hasil perhitungan statistic

Dari tabel di atas dapat dibuat persamaan regresi linier berganda sebagai berikut :

$$
\mathrm{Y}=1.304+0.533 \mathrm{X} 1+0.301 \mathrm{X} 2+0.334 \mathrm{X} 3+\mathrm{e}
$$

Persamaan di atas mempunyai arti bahwa jika kepemimpinan kepala sekolah (X1) naik satu satuan, maka etos kerja guru (Y) akan naik sebesar 0.533 satuan dengan anggapan variabel yang lain konstan. Jika penerapan disiplin kerja (X2) naik satu satuan, maka etos kerja guru (Y) akan naik sebesar 0.301 satuan dengan anggapan variabel yang lain konstan. Jika pengawasan (X3) naik satu satuan, maka etos kerja guru (Y) akan naik sebesar 0.334 satuan dengan anggapan variabel yang lain konstan.

Nilai R sebesar 0.624 berarti bahwa hubungan antara variabel-variabel bebas kepemimpinan kepala sekolah, penerapan disiplin, dan pengawasan terhadap variabel terikat yaitu etos kerja guru adalah erat dan kuat. Hal ini ditandai dengan nilai $\mathrm{R}$ di atas $50 \%$ yaitu sebesar $68.5 \%$.

Nilai determinasi simultan ( $\mathrm{R}$ square) sebesar 0,605 artinya bahwa variasi berubahnya etos kerja guru dipengaruhi oleh kepemimpinan kepala sekolah, penerapan disiplin, dan pengawasan sebesar 60,5\% sedangkan sisanya sebesar 39,5\% dipengaruhi oleh variabel lain yang tidak diteliti.

Pengujian Hipotesis Pertama. Hipotesis yang pertama adalah diduga terdapat pengaruh signifikan antara variabel kepemimpinan kepala sekolah, penerapan disiplin, dan pengawasan secara bersama-sama (simultan) terhadap variabel etos kerja guru.

Tabel 2

\section{Hasil Perhitungan Uji Simultan (Uji F)}

\begin{tabular}{|l|l|l|l|l|l|l|l|}
\hline Source & Df & $\begin{array}{l}\text { Sum of } \\
\text { Square }\end{array}$ & $\begin{array}{l}\text { Mean } \\
\text { Square }\end{array}$ & F stat & $\begin{array}{l}\text { Signf } \\
\text { F }\end{array}$ & $\begin{array}{l}\text { F } \\
\text { tabel }\end{array}$ & $\begin{array}{l}\text { Keter } \\
\text { ngan }\end{array}$ \\
\hline Regression & 3 & 228840,49427 & 57210,12357 & 10,0539 & 0,000 & 2,98 & $\begin{array}{l}\text { Signifi } \\
\text { kan }\end{array}$ \\
\hline Residual & 241 & 276121,73631 & 3681,62315 & & & & \\
\hline Total & 244 & 504962,23058 & 60891,74672 & & & & \\
\hline $\begin{array}{l}\text { Multiple R } \\
60,67638\end{array}$ & 0,67319 & & & \\
6
\end{tabular}

Perhitungan regresi linier berganda menghasilkan nilai Fhitung sebesar 10.053 Ftabel sebesar 2.98 dengan df pembilang 3 dan penyebut 241. Dengan demikian maka terbukti bahwa Fhitung lebih besar daripada Ftabel yang berarti Ho ditolak dan menerima Ha pada tingkat signifikansi sebesar 0.000. Artinya bahwa terdapat pengaruh yang signifikan variabel-variabel kepemimpinan kepala sekolah, penerapan disiplin, dan pengawasan secara bersama-sama (simultan) terhadap etos kerja guru. 
733 Analisis Kepemimpinan Kepala Sekolah, Penerapan Disiplin, Dan PengawasanTerhadap Etos KerjaSuyitno

DOI: https://doi.org/10.31004/edukatif.v3i3.438

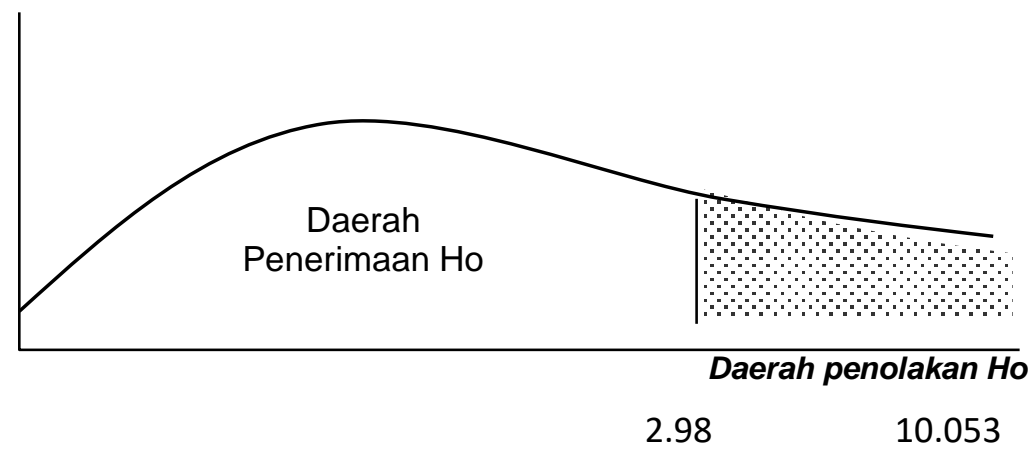

Gambar 1

\section{Daerah Penolakan Ho Pada Uji F}

Pengujian Hipotesis Kedua. Hipotesis yang kedua adalah diduga terdapat pengaruh signifikan antara variabel kepemimpinan kepala sekolah, penerapan disiplin, dan pengawasan secara parsial terhadap variabel etos kerja guru. Pengujian hipotesis yang kedua ini dengan menggunakan uji t.

Tabel 3 Hasil Perhitungan Uji-t

\begin{tabular}{|ll|c|c|c|}
\hline \multirow{2}{*}{ Model } & & $\mathrm{t}$ & Sign & Keterangan \\
\hline 1 & $\mathrm{X} 1$ & 3.974 & 0.000 & Ho ditolak \\
& $\mathrm{X} 2$ & 2.612 & 0.013 & Ho ditolak \\
& $\mathrm{X} 3$ & 2.949 & 0.005 & Ho ditolak \\
\hline
\end{tabular}

Derajat kebebasan $\mathrm{df}=(\mathrm{n}-\mathrm{k}-1)=244-3-1=240$ dan tingkat taraf kepercayaan 5\% atau 0.05, maka nilai $\mathrm{t}_{\text {tabel }}$ adalah sebesar 2.056. Adapun penjelasan pada masing-masing variabel sebagai berikut:

Variabel Kepemimpinan Kepala Sekolah (X1) . Nilai thitung dalam penelitian ini adalah sebesar 3.974 dengan tingkat signifikansi sebesar 0.000 lebih besar dari $t_{\text {tabel }}$ sebesar 2.056. Hal ini menunjukkan bahwa terjadi penolakan Ho dan penerimaan $\mathrm{Ha}$ yang berarti terdapat pengaruh yang signifikan variabel kepemimpinan kepala sekolah terhadap variabel etos kerja guru.

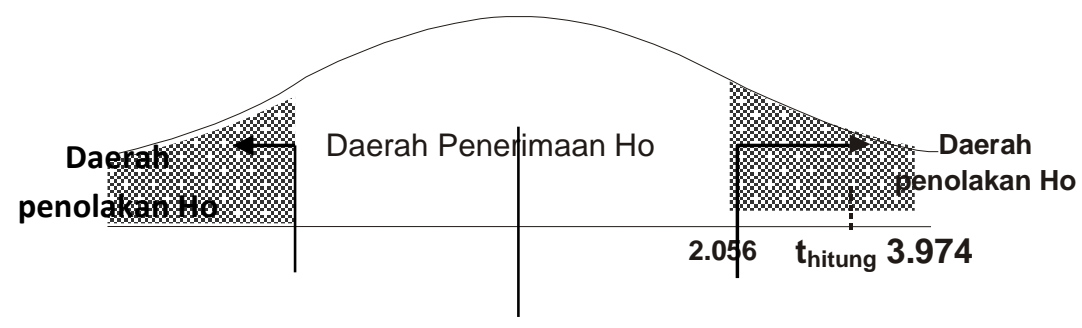

Gambar 2

Daerah Penolakan Ho Pada Uji t (2-tail)

Variabel Kepemimpinan Kepala Sekolah $\left(\mathbf{X}_{1}\right)$

Temuan ini sejalan dengan hasil penelitian Luthfi and Fadhilah (2020), yang menyatakan bahwa ada hubungan yang signifikan antara gaya kepemimpinan transformasional kepala sekolah dan etos kerja guru beserta staf dengan nilai koefisien sebesar 0,370. 
Penerapan Disiplin $\left(\mathrm{X}_{2}\right)$.Nilai $\mathrm{t}_{\text {hitung }}$ dalam untuk variabel ini ini adalah sebesar 2.133 dengan tingkat signifikansi sebesar 0.039 lebih besar dari $t_{\text {tabel }}$ sebesar 2.056. Hal ini menunjukkan bahwa terjadi penolakan Ho dan penerimaan Ha yang berarti terdapat pengaruh yang signifikan variable penerapan disiplin terhadap variabel etos kerja guru.

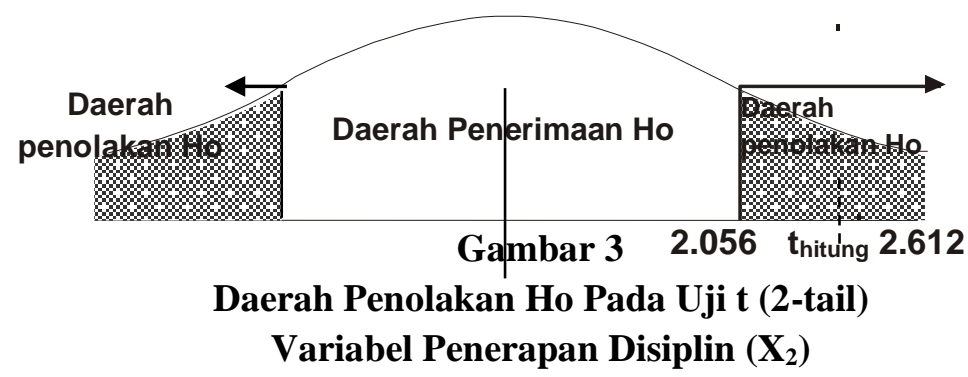

Hasil penelitian ini sejalan dengan penelitian yang dilakukan oleh Gustinsia, Vietriana (2016) yang menyatakan bahwa kepemimpinan, lingkungan kerja dan disiplin kerja pegawai Bank Bengkulu memiliki pengaruh yang signifikan terhadap etos kerja Bank Bengkulu Curup. Penelitian Evendi Mamak M Balafif (2018) juga menunjukkan bahwa secara simultan maupun parsial variabel hubungan antar karyawan, kondisi lingkungan kerja dan disiplin kerja berpengaruh signifikan terhadap etos kerja karyawan PT. Korin Surabaya.

Pengawasan $\left(\mathrm{X}_{3}\right)$. Nilai $\mathrm{t}_{\text {hitung }}$ untuk variabel pengawasan dalam penelitian ini adalah sebesar 2.949 dengan tingkat signifikansi sebesar 0.005 lebih besardari $t_{\text {tabel }}$ sebesar 2.056. Hal ini menunjukkan bahwa terjadi penolakan Ho dan penerimaan Ha yang berarti terdapat pengaruh yang signifikan variabel pengawasan terhadap variabel etos kerja guru.

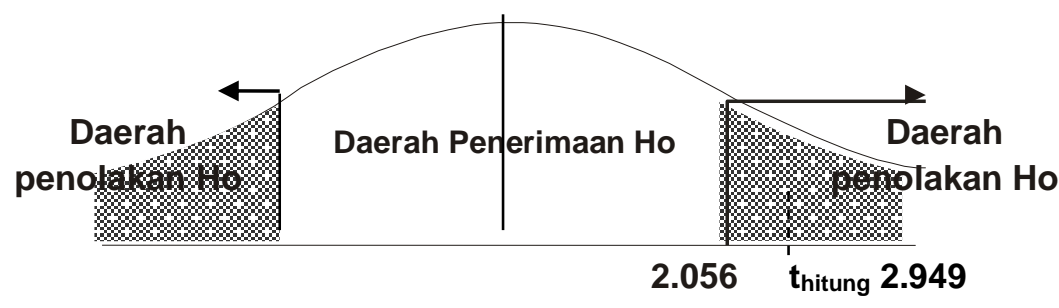

\section{Gambar 4 \\ Daerah Penolakan Ho Pada Uji t (2-tail) \\ Variabel Pengawasan $\left(\mathbf{X}_{3}\right)$}

Temuan penelitian ini sejalan dengan hasil penelitian yang dilakukan oleh Sukatno and Juhri (2017) yang menunjukkan terdapat pengaruh positif dan signifikan bahwa supervisi akademik terhadap etos kerja guru sekolah di SMK Negeri se Lampung Timur. Supervisi yang didalamnya terdapat unsur pengawasan terhadap tingkat pemahaman terhadap tugas dan prosedur kerja, tingkat kemampuan menyelesaikan tugastugas yang dibebankan, dan frekuensi pemberian sanksi. Pengawasan adalah usaha atau tindakan meneliti apakah segala sesuatu tercapai atau berjalan sesuai dengan rencana yang telah ditetapkan berdasarkan intraksi yang telah ditetapkan atasan. Pengawasan dapat diartikan mengerahkan prestasi kerja dan apakah perlu mengadakan tindakan-tindakan korektif, sehingga hasil-hasil kegiatan sesuai dengan rencana-rencana. 
Pengujian Hipotesis Ketiga paling dominan terhadap variabel terikat. Untuk lebih jelasnya dapat disajikan pada tabel berikut: Selanjutnya, untuk pengujian hipotesis yang ketiga adalah melihat variabel mana diantara variabel bebas yang berpengaruh

\section{Tabel 4}

\section{Hasil Perhitungan Uji t}

\begin{tabular}{|ll|c|c|c|}
\hline \multicolumn{2}{|c|}{ Variabel } & \multicolumn{2}{c|}{ Correlations } & \multirow{2}{*}{ Keterangan } \\
\cline { 3 - 4 } & Partial & Part & \\
\hline Kepemimpinan kepala sekolah $\left(\mathrm{X}_{1}\right)$ & 0.542 & 0.481 & \multirow{2}{*}{ Dominan } \\
Penerapan Disiplin Kerja $\left(\mathrm{X}_{2}\right)$ & 0.390 & 0.253 & \\
Pengawasan $\left(\mathrm{X}_{3}\right)$ & 0.253 & 0.210 & \\
\hline \multicolumn{2}{|c}{ Sumber : data diolah } \\
\hline
\end{tabular}

Dari tabel di atas dapat dilihat bahwa secara parsial seluruh variabel bebas berpengaruhterhadap variabel terikat (etos kerja guru). Oleh karena itu dari keseluruhan variabel bebas yang berpengaruh, maka variabel yang mempunyai pengaruh dominan adalah variabel kepemimpinan kepala sekolah $\left(\mathrm{X}_{1}\right)$ dengan nilai koefisien determinasi sebesar 0.542 lebih besar dibandingkann dengan nilai koefisien determinasi untuk variabel yang lain.

Dengan demikian hipotesis ketiga yang berbunyi: diduga terdapat variabel berpengaruh paling dominan terhadap variabel etos kerja telah terbukti dengan menghasilkan kepemimpinan kepala sekolah sebagai variabel yang berpengaruh paling dominan terhadap etos kerja guru. Berdasarkan hasil penelitian tersebut menunjukkan bahwa sebagai upaya untuk meningkatkan etos kerja guru SMA se Kabupaten Tulungagung dapat dilakukan dengan meningkatkan kualitas kepemimpinan kepala sekolah. Hal ini sejalan dengan penelitian yang dilakukan oleh Herana Budi (2020) dan Luthfi and Fadhilah (2020). Peningkatan kualitas kepemimpinan kepala sekolah dapat dilakukan dengan mengoptimalkan aspek- aspek sesuai dengan indikator yang digunakan dalam penelitian ini yakni kepribadian, pengetahuan terhadap tenaga kependidikan, visi dan misi sekolah, kemampuan mengambil keputusan, dan kemampuan berkomunikasi.

Kepala sekolah memiliki peran strategis dalam menentukan kebijakan penyelenggaraan proses belajar mengajar di suatu lembaga pendidikan yang dipimpinnya. Kepala sekolah bertanggung jawab atas keberhasilan dan kegagalan pendidikan di sekolah, termasuk masalah etos kerja guru. Kepemimpinan merupakan merupakan salah satu fungsi manajemen dimana seorang pemimpin mengarahkan, dan mempengaruhi bawahannya atau orang lain untuk melaksanakan suatu tugas tertentu. Jika kepemimpinan kepala sekolah dijalankan dengan kepribadian yang baik, memiliki pengetahuan terhadap kuantitas dan kualitas bawahan baik guru maupun tenaga pendidik, internalisasi visi dan misi sekolah, kemampuan mengambil keputusan, dan kemampuan berkomunikasi, maka secara langsung akan berpengaruh kepada etos kerja guru-guru SMA Negeri se Kabupaten Tulungagung.

Penelitian ini dilaksanakan beberapa keterbatasan sehingga peneliti-peneliti selanjutnya dapat lebih menyempurnakan dalam penelitian-penelitian kedepannya. Beberapa keterbatasan dalam penelitian tersebut, antara lain jumlah responden yang hanya 244 orang, tentunya masih kurang untuk menggambarkan keadaan yang sesungguhnya, objek penelitian hanya di fokuskan pada variabel etos kerja guru yang dijelaskan melalui variabel kepemimpinan kepala sekolah, pengawasan dan penerapan kedisiplinan, yang tentunya masih banyak variabel yang bisa menjelaskan etos kerja guru tersebut. Keterbatasan selanjutna dalam proses pengambian data, informasi yang diberikan responden melalui kuesioner terkadang tidak menunjukkan pendapat responden yang sebenarnya yang disebabkan karena kadang perbedaan pemikiran, kejujuran, anggapan, pemahaman yang berbeda tiap responden. 

Suyitno

DOI: https://doi.org/10.31004/edukatif.v3i3.438

\section{KESIMPULAN}

Berdasarkan hasil penelitian yang telah dilakukan maka dapat diambil kesimpulan bahwa 1) hubungan antara variabel-variabel bebas kepemimpinan kepala sekolah, penerapan disiplin, dan pengawasan terhadap variabel terikat yaitu etos kerja guru adalah erat dan kuat. 2) secara parsial variabel kepemimpinan kepala sekolah, penerapan disiplin dan pengawasan berpengaruh signifikan terhadap etos kerja guru, 3) variabel kepemimpinan kepala sekolah, penerapan disiplin dan pengawasan secara simultan berpengaruh signifikan terhadap etos kerja guru, 4) diantara variabel kepemimpinan kepala sekolah, penerapan disiplin dan pengawasan, variabel kepemimpinan kepala sekolah berpengaruh dominan terhadap etos kerja guru.

\section{DAFTAR PUSTAKA}

Ballu, S. S., Manu, L. and Meha, A. M. (2021) 'Analisis Peran Supervisi Akademik Kepala Sekolah Kepada Guru IPA DI SMP Negeri 20 Kupang’, Edukatif: Jurnal Ilmu Pendidikan, 3(1), pp. 20-26. Available at: https://www.edukatif.org/index.php/edukatif/article/view/161.

Chadijah, C. (2019) 'Supervisi Akademik Pengawas Sekolah dalam Meningkatkan Etos Kerja Mandiri Guru SD Kota Lhokseumawe', Jurnal Serambi Akademica, 7(3), pp. 321-327. Available at: http://jurnal.serambi mekkah.ac.id/serambi-akademika/article/view/1370.

Evendi, Mamak M Balafif, I. N. (2018) 'Pengaruh Hubungan Antar Karyawan , Kondisi Lingkungan Kerja Dan Disiplin Kerja Terhadap Etos Kerja Karyawan PT . Korin Surabaya. Jurnal Manajemen Branchmarck Universitas Bhayangkara Surabaya, 4(3), pp. 242-253.

Fitri, E. N. and Hakim, D. R. (2020) 'Optimalisasi Etos Kerja Guru SMK Jakarta Barat Melalui Budaya Organisasi dan Kecerdasan Emosional', Equilibrium : Jurnal Penelitian Pendidikan dan Ekonomi, 17(1), pp. 35-43. doi: 10.25134/equi.v17i01.

Gun Gun Gunanjar dkk (2019) Pengawasan Dengan Partisipasi Masyarakat Dan Penerapannya Di Indonesia 'Jurnal Pengawasan', 1(1), pp. 18-28.

Gustinsia, Vietriana and Ridwan, Nurazi and Syamsul, B. (2016) 'Pengaruh Kepemimpinan, Lingkungan Kerja Dan Disiplin Kerja Terhadap Etos Kerja Karyawan Pada Bank Bengkulu Capem Wilayah Curup', The Manager Review (Jurnal Ilmiah Manajemen). Available at: http://repository.unib.ac.id/id/eprint/11418.

Hanif Nur Hidayah1, B. S. (2019) 'Sistem Kompensasi dan Kepuasan Kerja Guru Tidak Tetap di Sebuah SMK Swasta di Indonesia', Jurnal Pendidikan Manajemen Perkantoran, 4(2), p. 141. doi: 10.17509/jpm.v4i2.18008.

Herana Budi (2020) 'Etos Kerja Guru Melalui Pengaruh Kepemimpinan Kepala Sekolah Sd Negeri Alue Punti', Jurnal Al-Azkiya: Volume 5 Nomor 1 Tahun 2020, 5(1), pp. 68-75.

Ja'far, J. (2019) 'Inovasi Kepemimpinan Kepala Madrasah Kreatif Dalam Meningkatkan Mutu Pendidikan Di Sekolah', Journal EVALUASI, 3(1), p. 74. doi: 10.32478/evaluasi.v3i1.215.

Ketut Sukarma, Nyoman Dantes, M. S. (2014) Pengaruh Implementasi Supervisi Klinis Terhadap Etos Kerja Dan Keterampilan Mengelola Pembelajaran Pada Para Guru Sd Se-Kecamatan Buleleng ' $e$ Journal Program Pascasarjana Universitas Pendidikan Ganesha Program Studi Pendidikan Dasar (Volume 3 Tahun 2013)', Sage Journal, 3(1), pp. 1-11. Available at: https://www.academia.edu/4879643/_.

Luthfi, M. and Fadhilah, Z. (2020) 'Pengaruh Gaya Kepemimpinan Transformasional Kepala Sekolah Terhadap Etos Kerja Guru dan Staf, Jurnal Manajemen Pendidikan 2(2), pp. 206-224.

Mutakallim (2016) 'Pengawasan, Evaluasi dan Umpan Balik Stratejik', Jurnal Inspiratif-Pendidikan Volume V, Nomor 2, V(Juli-Desember 2016), pp. 351-365. 3.

Pandipa, K. (2018) Pentingnya Disiplin Kerja Terhadap Peningkatan Efektivitas Kerja Pegawai Pada Dinas 
737 Analisis Kepemimpinan Kepala Sekolah, Penerapan Disiplin, Dan PengawasanTerhadap Etos KerjaSuyitno

DOI: https://doi.org/10.31004/edukatif.v3i3.438

Pemberdayaan Perempuan Dan Perlindungan Anak Kabupaten Poso', Jurnal Ilmiah Administratie, 10(2), pp. 1-94.

Puspitasari, F. F. (2019), Implementasi Pelayanan Prima Sebagai Upaya Meningkatkan Marketing Sekolah, Jurnal Manajemen Pendidikan Islam. 4(1).

Siagian, K. V. (2016) 'Kualitas Pelayanan Publik Dan Kedisiplinan Tenaga SDM di Poliklinik Gigi dan Mulut BLU RSUP Prof. Dr. R. D. Kandou Manado. Jurnal e-GiGi (eG), Volume 4 Nomor 1, JanuariJuni 2016.

Sukatno, S. and Juhri, A. M. (2017) 'Pengaruh Supervisi Akademik Dan Disiplin Guru Terhadap Etos Kerja Guru Smk Negeri Se-Lampung Timur', Jurnal Lentera Pendidikan Pusat Penelitian LPPM UM Metro 2(2), pp. 179-187. Available at: https://ojs.ummetro.ac.id/index.php/lentera/article/view/704.

Wahyuningsih, N. (2016) 'Membangun Sikap Dan Etos Kerja Perspektif Syariah', Al-Amwal, 8(3), pp. 427436. doi: $10.24235 / a m w a l . v 8 i 2.484$. 